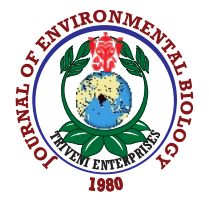

\title{
Partitioning of heavy metals in different environmental and biotic components in the coastal waters of the Straits of Malacca, Peninsular Malaysia
}

\author{
F. Md. Yusoff ${ }^{1,2}$, H.M.M. Peralta ${ }^{3}$, M. Shariff ${ }^{4}$ and S. Safura ${ }^{5}$ \\ 'International Institute of Aquaculture and Aquatic Sciences, University Putra Malaysia, Port Dickson 71050, Negeri Sembilan, Malaysia \\ ${ }^{2}$ Department of Aquaculture, Faculty of Agriculture, Universiti Putra Malaysia, 43400, UPM Serdang, Selangor, Malaysia \\ ${ }^{3}$ Freshwater Aquaculture Center - College of Fisheries, Central Luzon State University, 3120 Science City of Muñoz, Nueva Ecija, Philippines \\ ${ }^{4}$ Aquatic Animal Health Unit, Faculty of Veterinary Medicine, Universiti Putra Malaysia, 43400 UPM Serdang, Selangor, Malaysia \\ ${ }^{5}$ Department of Biology, Faculty of Science, Universiti Putra Malaysia, 43400 UPM Serdang, Selangor, Malaysia \\ *Corresponding Author Email : fatimamy@upm.edu.my
}

\section{Abstract}

Aim: Heavy metal contents in copepods, waters and sediments from an unpolluted Gula estuary, off a mangrove area in Perak $\left(0455.185^{\prime} \mathrm{N}\right.$, 10027.761'E), were compared with those from a polluted Juru estuary, off an industrial area in Penang (05 19.906'N, 10022.949 'E), Peninsular Malaysia.

Methodology: Triplicate composite water, copepod and sediment samples were collected for a period of one year at one-month interval from three permanent stations in the coastal waters off a mangrove forest in Gula estuary, and near an industrial area in Juru estuary.

Results: Copepods and sediments from Juru estuary contained significantly higher $(\mathrm{p}<.05)$ concentrations of $\mathrm{Zn}, \mathrm{Cu}, \mathrm{Pb}$, and $\mathrm{Cd}$ compared to those from Gula estuary. In fact, these heavy metal concentrations were also significantly higher $(p<0.05)$ in the water columns of Juru estuary than in Gula coastal waters. According to Pearson correlation coefficient analysis, significant correlations $(p<0.05)$ were observed between heavy metal contents in copepods and sediments $(\mathrm{Zn}, \mathrm{r}=0.664 ; \mathrm{Cu}, \mathrm{r}=0.603$; $\mathrm{Pb}, \mathrm{r}=0.568 ; \mathrm{Cd}, \mathrm{r}=0.501)$, but no significant correlation ( $p>0.05)$ was noted between heavy metal concentrations in water and copepods in both estuaries.

Interpretation: The concentration of heavy metals in sediments and copepods were relatively more stable than those in the water column, indicating that copepods and sediments could serve as more useful and reliable markers for environmental monitoring than seawater.

Keywords: Coastal waters, Heavy metals, Industrial area, Mangrove forest, Marine copepod, Sediment.

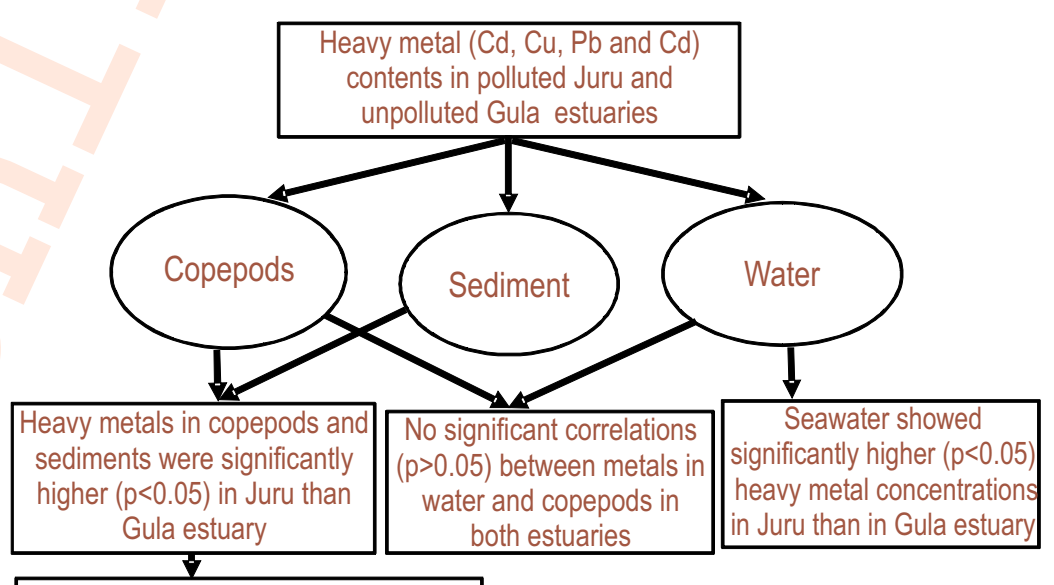

Heavy metal concentrations in copepods Copepods and sediments could serve as were positively correlated $(p<0.05)$ with those in sediments more useful and reliable markers for

environmental monitoring than the seawater

How to cite : Yusoff, F.Md., H.M.M. Peralta, M. Shariff and S. Safura: Partitioning of heavy metals in different environmental and biotic components in the coastal waters of the Straits of Malacca, Peninsular Malaysia. J. Environ. Biol., 41, 1371-1381 (2020). 


\section{Introduction}

Rapid industrial developments without proper waste treatments have resulted in an increased amount of pollutants released into the environment. Heavy metals such as lead $(\mathrm{Pb})$ and cadmium (Cd) are dangerous to many organisms in coastal waters as these harmful substances can cause negative impacts on organisms along the marine food chain, as well as other top consumers including humans. The threats are serious since these substances cannot be broken down by environmental processes and they are bioaccumulated and biomagnified to toxic levels (Harte et al., 1991; Schüürmann and Market 1988; Shartooh et al., 2013; Al-Imarah et al., 2018; Hong et al., 2020). With increased industrial, agricultural and other economic development activities in coastal areas, trace amount of heavy metals in the marine environment have been amplified to the levels that are unfavourable to aquatic life (Kalay and Canli, 2000; Looi et al., 2013). Consequently, most heavy metals discharged into coastal waters are related to inputs from anthropogenic activities, atmospheric deposition and surface runoffs (Veena et al., 1997; Bhattacharya et al., 2015; Balogh etal., 2016).

Heavy metal contamination in aquatic ecosystems have caused many negative consequences to environmental and human health mainly due to their accumulation in marine organisms, and consumption by top predators (such as fish, birds and marine mammals) and humans (Davies, 1978; Looi et al., 2013; Zeitoun and Mehana, 2014; Fatima et al., 2014). The uptake of these hazardous metals by plankton provides information and entry marine food chains (Gajbhiye et al., 1985; Haris et al., 2017). However, there is a considerable speculation about the partitioning of these substances in coastal waters and their transfer through various trophic levels along the marine food chain, especially in tropical areas, where food webs are complex (Wang, 2002; Zetina-Rejon et al., 2003)

Studies on heavy metal contamination in the Straits of Malacca, especially in fish and shellfish, date back to more than 20 years ago (Babji et al., 1979; Jothy et al., 1983; Law and Singh, 1988; Yap et al., 2004a, 2004b). Coastal waters bordering areas with active anthropogenic activities experience serious impacts from industrial, agricultural and urban waste discharges. Primary consumers in such areas are small copepods such as Acartia, Paracalanus, Temora and Oithona (Turner, 2004; Duggan et al., 2008; Serranito et al., 2016). However, information on heavy metal concentrations in lower trophic groups such as phytoplankton and zooplankton is limited (Rezai et al., 1999, 2003), yet information regarding heavy metal contents in primary consumers, particularly copepods, is important to understand the impacts on higher trophic groups in the coastal food chain. Therefore, this study aimed to assess the partitioning of commonly found heavy metals including $\mathrm{Cd}, \mathrm{Cu}, \mathrm{Pb}$ and $\mathrm{Zn}$ in seawater, sediment and copepods in polluted and unpolluted estuaries in order to illustrate the relationship between heavy metal contamination in different environmental (sediment and water) and biotic (copepods) compartments .

\section{Materials and Methods}

Sampling location : Three permanent stations approximately 1 $\mathrm{km}$ from the shore were randomly selected in the coastal waters off a mangrove forest along Gula estuary in Perak and the coastal waters off an industrial area along Juru estuary in Penang. The sampling sites were located in a relatively homogenous shallow area with a maximum depth of approximately $3 \mathrm{~m}$ (Fig. 1).

Sample collection : Triplicate composite water samples were collected at each sampling station using a Niskin water sampler on a monthly basis for a period of one year to cover annual seasonal changes. Samples were filter-sterilized through a 0.45 membrane filters, acidified with few drops of nitric acid $\left(\mathrm{HNO}_{3}\right)$ and kept in acid-washed sample bottles before further analyses. For the sediment analysis, samples from top $4-5 \mathrm{~cm}$ of sediment surface were collected using an Ekman grab and transferred to labelled acid-washed (acid bath 10\% $\mathrm{HCl}$ ) plastic bags and kept in a refrigerated box. Zooplankton samples were collected using a zooplankton net (100 $\mu \mathrm{m}$ mesh size) towed vertically from the deepest depth (approximately $20 \mathrm{~cm}$ from the bottom). Samples were then transferred to labelled sample bottles and kept cold in an ice-box to be carried off to the laboratory.

\section{Analyses of metal contents}

Seawater : Upon arrival at the laboratory, water samples were allowed to reach room temperature (approximately $27^{\circ} \mathrm{C}$ ), and 10 $\mathrm{ml}$ of each filtered sample was subjected to metal analyses (Cd, $\mathrm{Cu}, \mathrm{Pb}$ and $\mathrm{Zn}$ ) using an air-acetylene flame atomic absorption spectrophotometer (AAS: Perkin-Elmer Model 800).

Sediment analysis : Sediment samples were dried at $105^{\circ} \mathrm{C}$ for at least $16 \mathrm{hr}$ until a constant dry weight was achieved. Dried samples were then pounded and sieved through a $63 \mu \mathrm{m}$ (mesh size) stainless steel sieve attached to an electronic sieve shaker (RETSCH 200 DIGIT USA). The sediments were shaken vigorously at $160 \mathrm{rpm}$ on orbital shaker (Gymromax model 722) for three hours to produce homogenous samples. For the analysis of metal concentration in sediments, direct aqua regia method (ISO1955:Scancar et al., 2000) was used. Sediment samples were then analysed using an air-acetylene flame AAS (Perkin-Elmer Model 800). Multiple-level calibration standards were used to generate calibration curves against which sample concentrations were calculated. Standard solutions were prepared from $1000 \mathrm{mg} \mathrm{I}^{-1}$ stock solution (MERCK Spectrosol) of each metal and the data were expressed in $\mu \mathrm{g} \mathrm{g}^{-1} \mathrm{~d}$.wt.

Copepods : After thawing to room temperature (approximately $27^{\circ} \mathrm{C}$ ), samples were sieved with a $63 \mathrm{~m}$ mesh size net and rinsed three times with distilled water to remove traces of salts. Copepods were sorted out from the zooplanktons before 


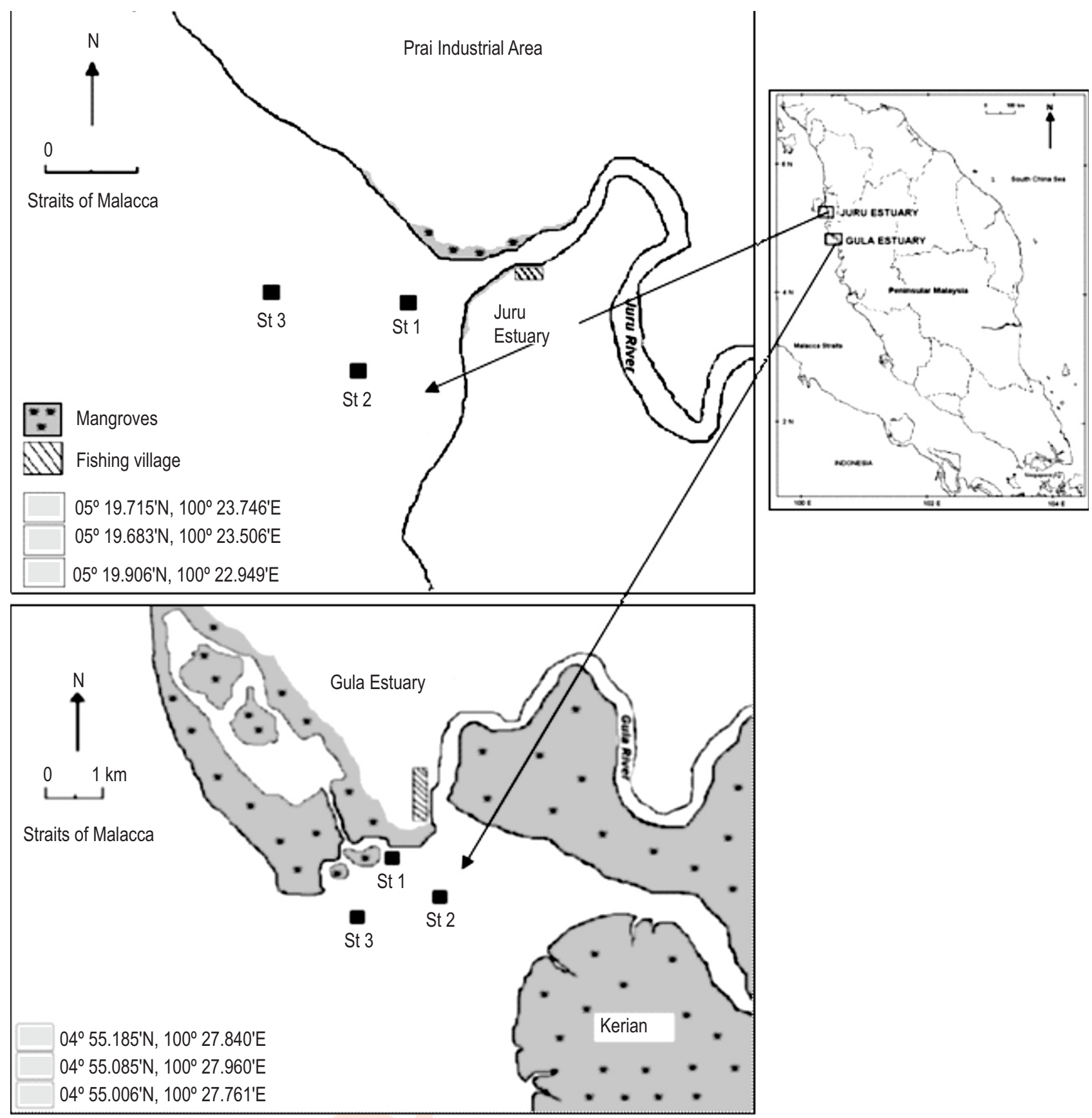

Fig. 1 : Map of sampling location in Juru estuary, off an industrial area in Penang, and Gula estuary, off a mangrove area in Perak.

digestion. Approximately, $0.5 \mathrm{~g}$ - $1.0 \mathrm{~g}$ of copepods were digested for $3 \mathrm{hrs}$ with $10 \mathrm{ml}$ concentrated $\mathrm{HNO}_{3}$ at $140{ }^{\circ} \mathrm{C}$. The digests were then made up to $40 \mathrm{ml}$ volume with deionized distilled water, after which heavy metal concentrations were analysed using AAS (Perkin-Elmer Model 800).

Quality control : To avoid possible contamination, all glassware and other materials used were acid washed. Procedural blanks and quality control samples made from standard solutions for $\mathrm{Cd}$,
$\mathrm{Cu}, \mathrm{Pb}$ and $\mathrm{Zn}$ were analysed every 5-10 samples to check for sample accuracy. Percentages of recovery for heavy metal analysis were acceptable at $80-100 \%$. The analytical procedure for heavy metal contents in copepods was checked with the Certified Referenced Material (CRM) for dogfish liver (DOLT-3, National Research Council Canada). The recoveries of all metals in this study were considered satisfactory at $80-100 \%$.

Statistical analyses : Mann-Whitney U-test and independent t- 
test were employed to assess the concentrations of $\mathrm{Cd}, \mathrm{Cu}, \mathrm{Pb}$ and $\mathrm{Zn}$ in different compartments (seawater, sediments and copepods) at different sites (Juru and Gula estuaries) using statistical software SPSS version 15.0. Spearman Rank Correlation was applied to examine the correlation between heavy metal concentrations and their partitioning amongst different environmental and biotic compartments (seawater, sediments, and copepods). Euclidean distance was used to construct a similarity index as the basis for a 2-D ordination of non-metric multi dimensional scaling (nMDS) using PRIMER (version 6.1.9, PRIMER-E Ltd) software package (Clarke and Warwick 2001).

\section{Results and Discussion}

Assessment of harmful metal levels in plankton (mainly copepods) is important because planktonic organisms are often the main diet for many aquatic predators. Thus, copepods play an important role in transferring these harmful elements from water and sediments to higher trophic levels, such as fish and other commercially important invertebrates that form important marine food product for human populations. This study showed that metal concentrations in copepods from Juru estuary were significantly higher $(p<0.05)$ than those in copepods from Gula estuary throughout the study period, indicating that the industrial area in Juru contributed higher levels of metals to the estuary compared to the mangrove area in Gula. In Juru estuary, $\mathrm{Cd}, \mathrm{Cu}$, $\mathrm{Pb}$ and $\mathrm{Zn}$ concentrations in copepods ranged from 0.31 to 2.55 $\mu \mathrm{g} \mathrm{g}^{-1}, 47.26$ to $66.19 \mu \mathrm{g} \mathrm{g}^{-1}, 47.96$ to $117.97 \mu \mathrm{g} \mathrm{g}^{-1}$ and 177.32 to 256.17 ug g $^{-1}$, respectively (Fig. 2). However, in Gula estuary, the metal concentrations were significantly lower, ranging from 0.00 to $1.57 \mu \mathrm{g} \mathrm{g}^{-1}, 17.02$ to $37.3 \mu \mathrm{g} \mathrm{g}^{-1}, 11.45$ to $24.25 \mu^{-1} \mathrm{~g}^{-1}$ and 43.69 to $73.02 \mu \mathrm{g} \mathrm{g}{ }^{-1}$ for $\mathrm{Cd}, \mathrm{Cu}, \mathrm{Pb}$ and $\mathrm{Zn}$, respectively (Fig. 2). Significantly lower $(p<0.05)$ metal concentrations in copepods from Gula compared to those in Juru $(p<0.05)$ were perhaps due to the presence of undisturbed mangrove forests and absence of metal-based industries in the former. According to Tam and Wong (1999) and Yunus et al. (2011), mangrove ecosystems (including vegetation and sediments) have the capacity to sequester chemical compounds from river and sea waters, and hence are known as natural sinks for heavy metals. Similarly, Machado et al. (2002) noted that the sediment metal load in the mangrove forest, which are predominantly in trace metal forms, have strong affinity to substrates and low possibility of remobilization and uptake by organisms. In addition, Zhou et al. (2010) encouraged constant renewal of mangrove forest cover, because this approach would help to increase the absorption of heavy metals by the mangrove forest floor and thereby decrease their availability in the estuarine and coastal waters. In fact, studies from Balakrishnan et al. (2017) and Sarkar (2017) have shown that mangroves can sequester trace metals from tidal waters. In addition, Lacerda (1998) noted that mangrove roots and above ground biomass could induce changes in sediment chemistry, which would decrease heavy metal availability and remobilization into estuarine and coastal waters.
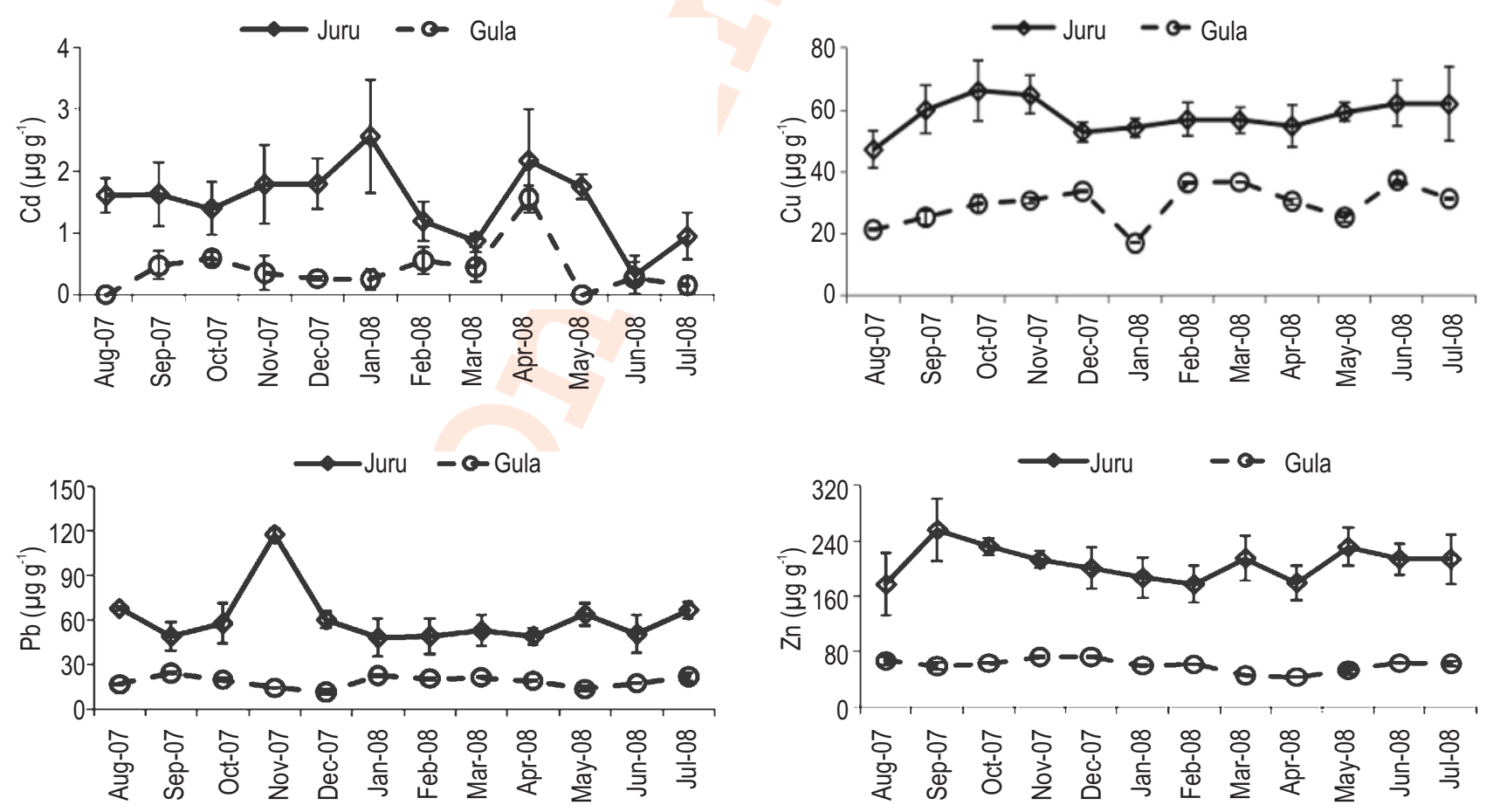

Fig. 2: Comparison of $\mathrm{Cd}, \mathrm{Cu}, \mathrm{Pb}$, and $\mathrm{Zn}$ concentrations in copepods throughout the study period in Juru and Gula estuaries. 

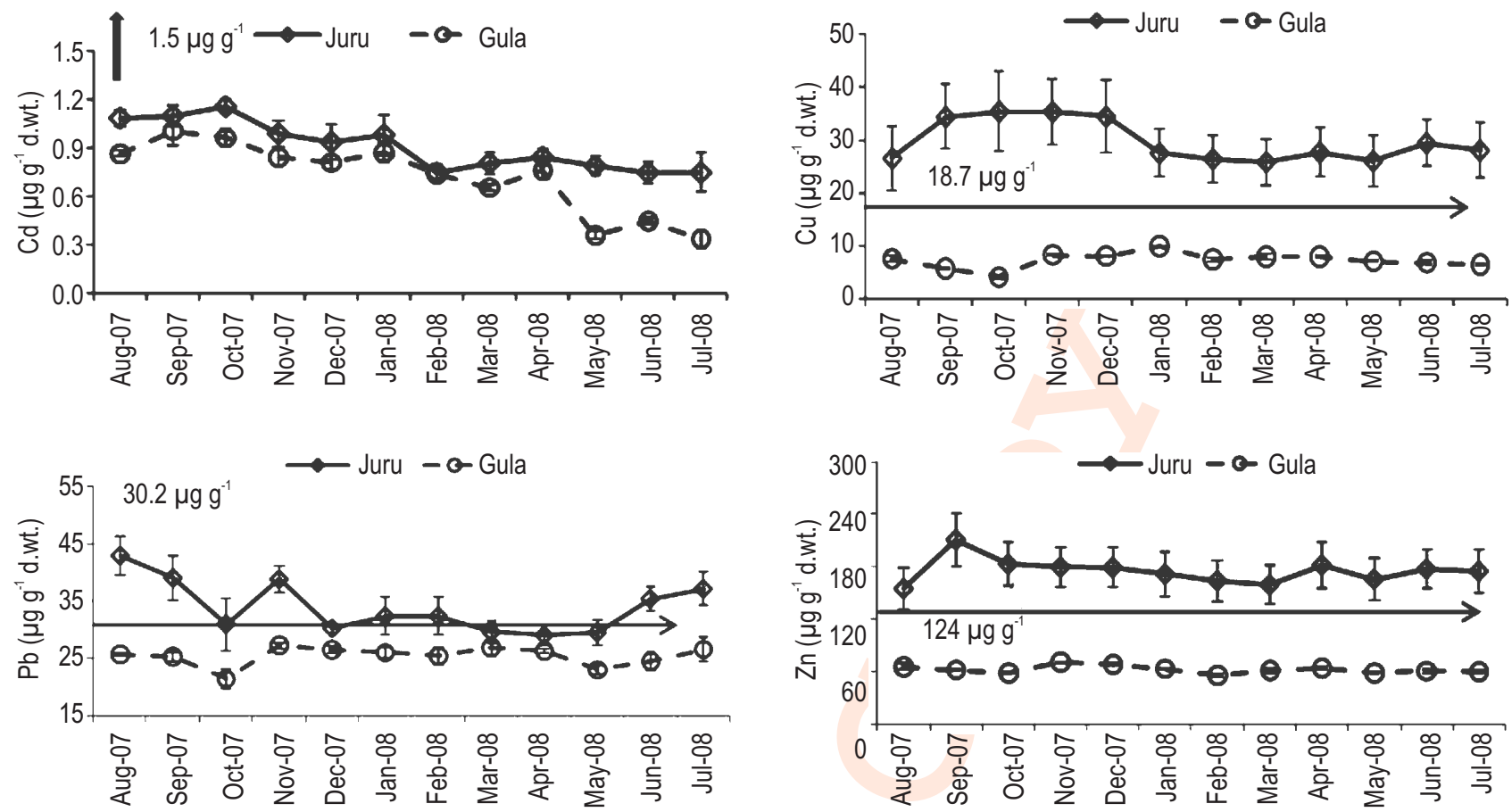

Fig. 3 Comparison of $\mathrm{Cd}, \mathrm{Cu}, \mathrm{Pb}$, and $\mathrm{Zn}$ concentrations $\left(\mu \mathrm{g} \mathrm{g}^{-1}\right)$ in sediment throughout the study period in Juru and Gula estuaries. Solid lines with an arrow indicate the International Sediment Quality Guidelines Canada (ISQ Guidelines, 1997).

Similar to copepods, Juru estuarine bottom sediments contained significantly higher $(p<0.05)$ concentration of heavy metals compared to Gula sediments throughout the year (Fig. 3). High concentration of metallic substances in Juru sediments could be due to prolonged exposure and accumulation of industrial waste discharges from the surrounding industrial area. Heavy metal levels in Juru estuarine sediment ranged from 0.24 to $1.40 \mu \mathrm{g} \mathrm{g}^{-1}, 9.56$ to $64.93 \mu \mathrm{g} \mathrm{g}^{-1}, 15.11$ to $59.46 \mu^{-1} \mathrm{~g}^{-1}$ and 72.08 to $303.59 \mathrm{\mu g} \mathrm{g}^{-1}$ for $\mathrm{Cd}, \mathrm{Cu}, \mathrm{Pb}$ and $\mathrm{Zn}$, respectively, which were higher than their respective permissible limits (Fig. 3). These concentrations, however, were lower than those reported by Mat and Maah (1994) in the intertidal mudflat of Juru and Muda estuaries, because their study location was nearer to the pollutant source (factory outlets) compared to the present study in the estuarine area. However, the results of study was comparable to those reported by Yap et al. $(2002,2003)$ who also noted that sediments in Gula estuary had significantly lower metal concentrations compared to those in Juru area. Accumulation of non-degradable pollutions such as heavy metals in sediments over a long period of time can exceed the concentrations in water columns (Lyons and Fitzgerald, 1980; Barron, 1995; Yi et al., 2008; Khan et al., 2018). Under this condition, sediments can serve as a sink as well as a source of pollutants such as heavy metals. Invertebrates and fish feeding at sea bottom can transfer these heavy metals to other components along the marine food chain.
Metal concentrations in estuarine waters fluctuated inconsistently throughout the year with no distinct patterns (Fig. 4), perhaps due to water dynamics related to current and tidal changes, which in turn influenced the concentration of heavy metals at both locations. Moreover, water dynamics are naturally influenced by many factors, such as rainfall and wastewater runoffs. In fact, according to Etim et al. (1991), it was difficult to estimate the amount of biologically available concentration based marine water analysies alone, and this problem necessitates the analyses of chemicals in the organism itself. In Juru estuarine waters, the concentration of heavy metals ranged from 0.01 to 0.12 $\mathrm{mgl}^{-1}, 0.01$ to $0.16 \mathrm{mg} \mathrm{l}^{-1}, 0.11$ to $1.31 \mathrm{mg} \mathrm{l}^{-1}$ and 0.01 to $0.12 \mathrm{mg} \mathrm{l}^{-1}$ for $\mathrm{Cd}, \mathrm{Cu}, \mathrm{Pb}$ and $\mathrm{Zn}$, respectively. However, in Gula estuary, heavy metal concentrations were significantly lower $(p<0.05)$ than those in Juru, ranging from 0.01 to $0.09 \mathrm{mg} \mathrm{l}^{-1}(\mathrm{Cd}), 0.01$ to $0.86 \mathrm{mgl}^{-}$ ${ }^{1}(\mathrm{Cu}), 0.02$ to $0.85 \mathrm{mg} \mathrm{l}^{-1}(\mathrm{~Pb})$ and 0.01 to $0.07 \mathrm{mgl}^{-1}(\mathrm{Zn})$.

Heavy metal contents in copepods and sediments were more consistent, with lower variability (maximum of eight order of magnitude) and distinct patterns, compared to those in water column, which experienced drastic fluctuation up to 16 times the lowest concentration (Fig. 2, 3, 4). A significantly higher $(p<0.05)$ concentration of heavy metals in Juru waters, copepods and sediments compared to those in Gula estuary might be attributed to industrialization and urbanization along the Juru coastal area. Wang and Fisher (1998) and Kadiene et al. (2019) found that copepods can completely assimilate ingested trace elements 

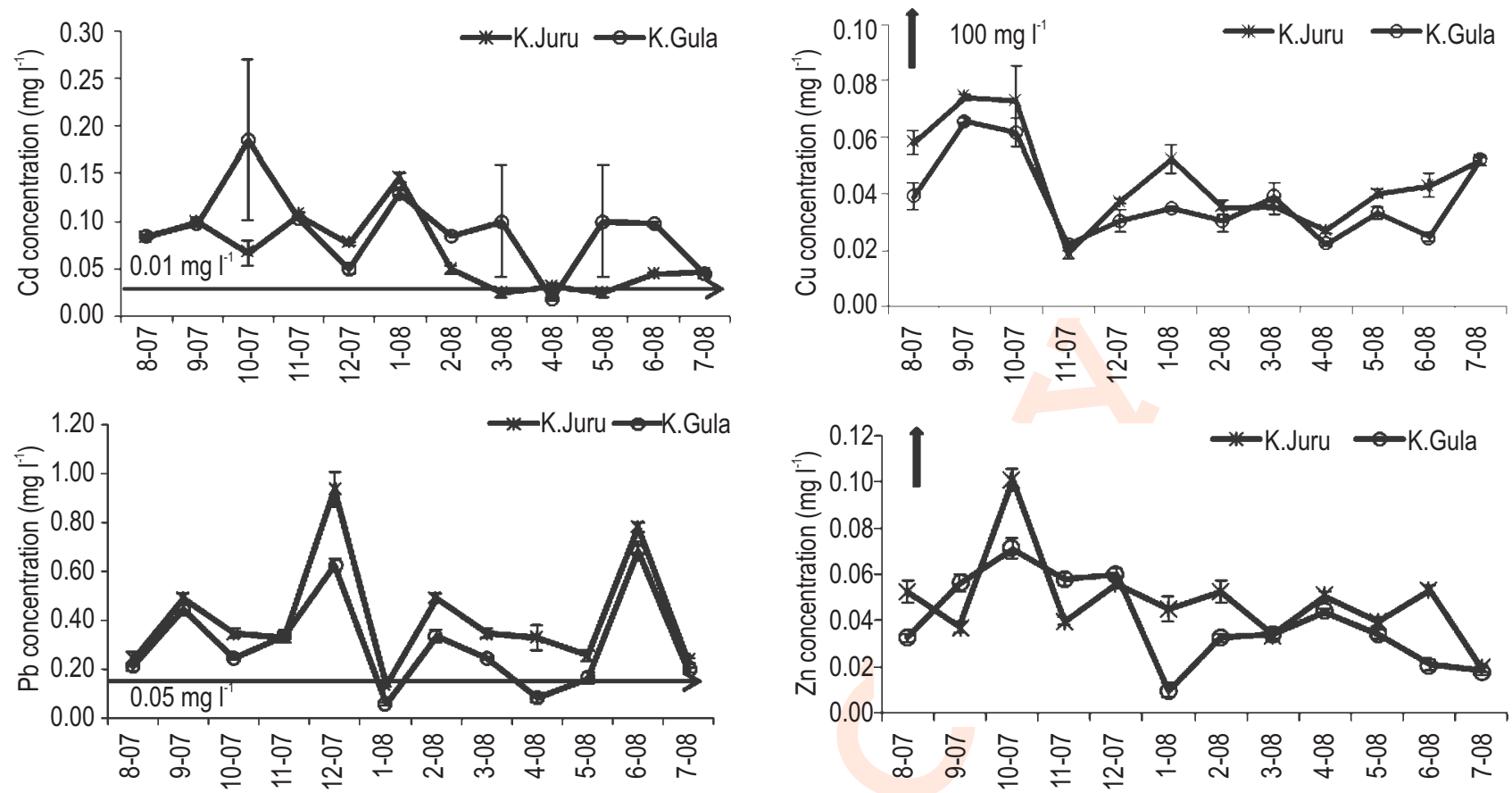

Fig. 4 : Comparison of $\mathrm{Cd}, \mathrm{Cu}, \mathrm{Pb}$ and $\mathrm{Zn}$ concentrations $\left(\mathrm{mg} \mathrm{l}^{-1}\right)$ in seawater throughout the study period in Juru and Gula estuaries. Solid lines with an arrow indicate the International Marine Water Quality Standard Malaysia (IMWQS Malaysia, 2005).
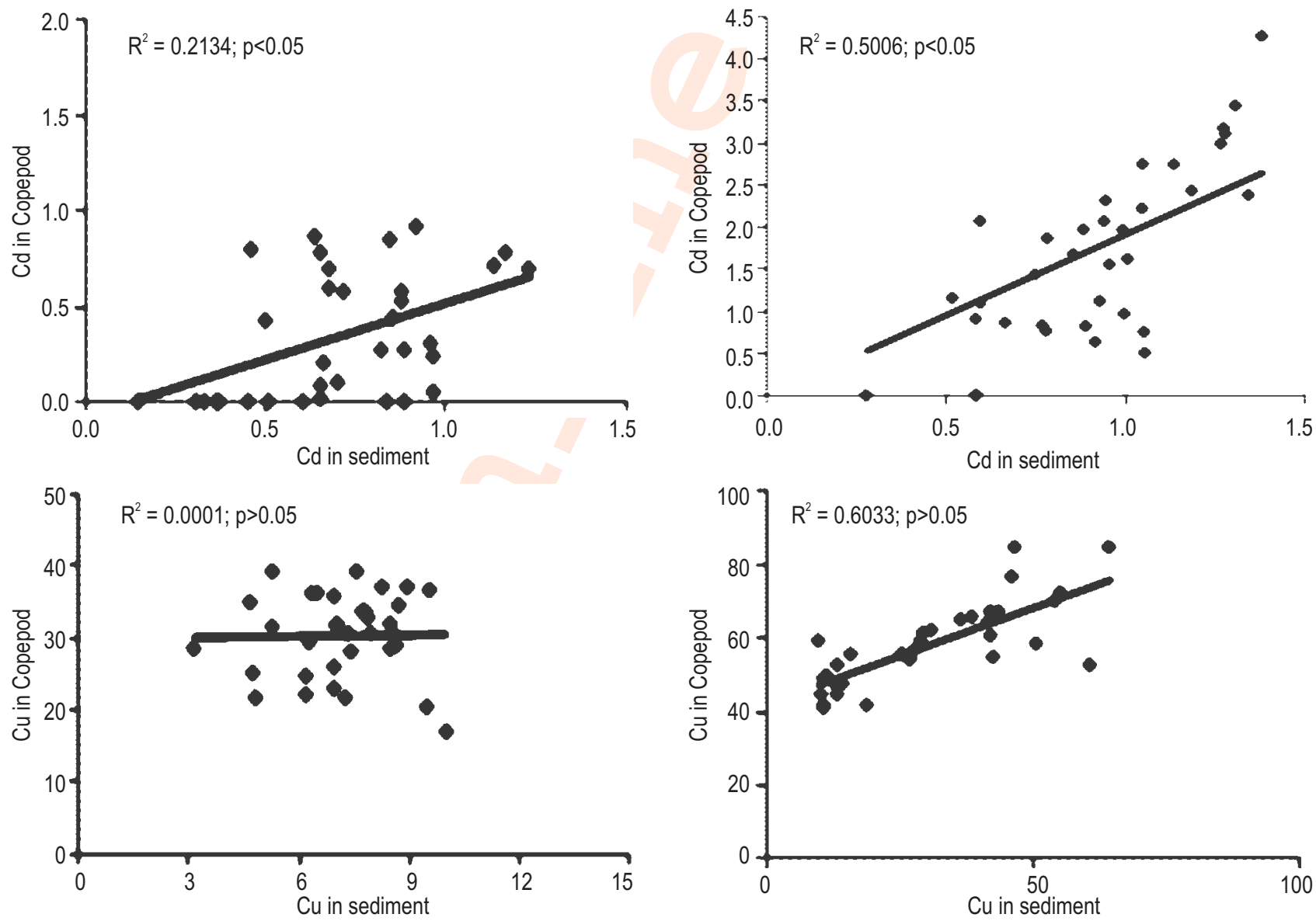

Fig. 5 Correlations of heavy metal concentrations ( $\mathrm{Cd}$ and $\mathrm{Cu}$ ) between sediments and copepods in Gula $(\mathrm{a}, \mathrm{c})$ and Juru (b, d) estuaries. 

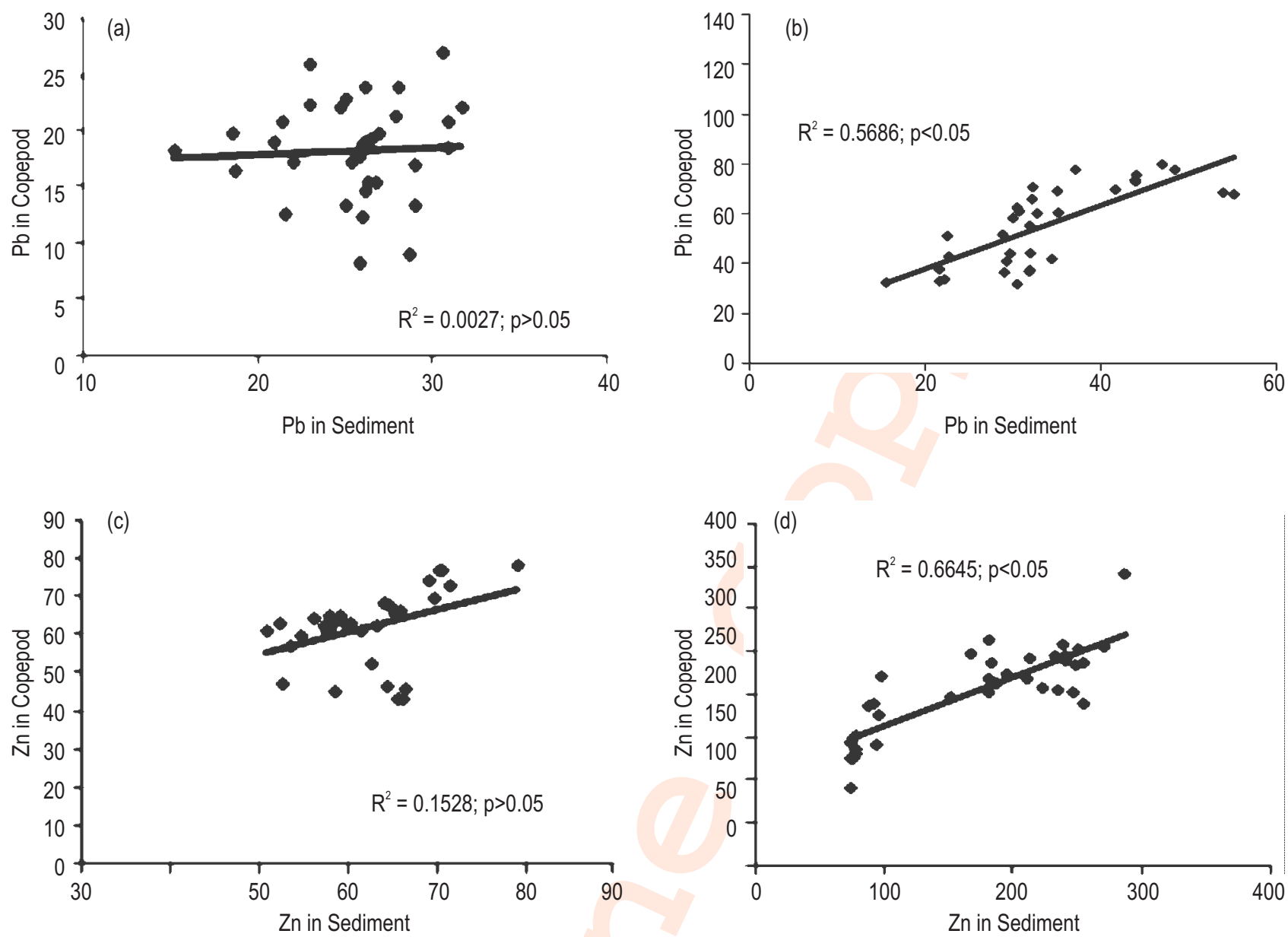

Fig. 6 : Correlations of heavy metal concentrations ( $P B$ and Zn) between sediments and copepods in Gula (a, c) and Juru (b, d) estuaries.

within $4-15$ hrs. This ability explains why the concentrations and bioavailability of heavy metals in copepods in Juru estuary were consistently detectable. The primary source of heavy metal contamination along the Juru estuary is due to factories discharging wastewaters directly into the coastal area. According to IMPAK (1998), the coastal waters along the Straits of Malacca are mainly polluted due to high input of organic and inorganic pollutants contributed mainly by human activities which could be land-based (agricultural and industrial wastes, sewage and domestic wastes, deforestation and land reclamation). In addition, sea-based activities can also be important source of pollution as the Straits of Malacca is the second busiest shipping lane in the world.

In this study, the concentration of heavy metal $(\mathrm{Cd}, \mathrm{Cu}, \mathrm{Pb}$ and $\mathrm{Zn})$ in copepods showed a significant correlation $(p<0.05)$ with those at the bottom sediment of Juru estuary (Fig. 5 and 6 ) indicating that there was an uptake of sediment particles containing heavy metals by copepods. Kontas (2008) and Khan et al. (2018) suggested that the mobilization of particulates from the bottom layer provided food particles to planktonic organisms, including copepods, although they were not in actual contact with the sediment. In fact, increased phytoplankton and chlorophyll a in the water column formed an important food source for the zooplankton partly due to mobilization of nutrients, especially inorganic nitrogen and phosphorus together with heavy metals from the enriched bottom sediment (Kontas 2008; Khan et al., 2018). In a polluted area, the bottom sediment plays a significant role in accumulation, storage and transport of metals among different environment and biotic compartments (Solomon et al., 1987). Dauvalter (1998) reported that metals in aquatic ecosystems tend to be adsorbed by suspended particulate matter that would finally sink to the bottom and become trapped in the sediment. In addition, Dawson and Macklin (1998) also noted that metals are transported either in solution or on the surface of suspended sediments as these metals have strong affinity to be adsorbed to particles (Lourna 1990; Robin et al., 2012; Rauf et al., 2018). In unpolluted Gula estuary, no significant correlation ( $p>0.05)$ was observed between copepods and sediments, probably due to a significant lower $(p<0.05)$ concentration of 



Fig. 7 : Correlations of heavy metal concentrations ( $\mathrm{Cd}, \mathrm{Cu}, \mathrm{Pb}$ and $\mathrm{Zn}$ ) between water and copepods in Juru (a,b,c,d) and Gula (e,f,g,h) estuaries.

heavy metals in this estuarine bottom sediment compared to those in the Juru area (Fig. 5, 6). Weak and/or absence of correlation between heavy metals in copepods and sediments in Gula estuary suggested that heavy metal concentrations in Gula sediments was too low to be mobilized to the water column and was not effectively transferred to the marine food chain.

No significant correlations ( $p>0.05)$ were observed between heavy metals in seawater and those in copepods in both Gula and Juru estuaries (Fig. 7). According to Davis (1978), Robin et al. (2012), and Rauf et al. (2018), there are two pathways through which zooplankton accumulate metals in their bodies either by direct uptake from water or assimilation from ingested food (phytoplankton/suspended organic particles). In this study, absence of significant correlation between heavy metal contents in seawater and copepods indicated that ingestion of suspended particles would be the main pathway of heavy metal uptake by the copepods. On the other hand, Fang et al. (2006) reported that the concentration of heavy metals in copepods were significantly correlated to the contaminated seawater in an outfall area, indicating that direct uptake can occur in the water column.

Results based on non-metric multidimensional scaling (nMDS) revealed two major groups with a Euclidean distance of 3.2. The first group was characterized by low metal concentrations, which mainly consisted of samples from coastal waters off Gula estuary. The second group was characterized by high heavy metal concentrations from the coastal waters off the Juru industrial area (Fig. 8). Similarly, metal concentration in copepods from Gula and Juru estuaries were separated into two groups with a Euclidean distance of 5.1 (Fig. 8). The nMDS showed distinct separation of two study sites in terms of metals contents in copepods and sediments, indicating that high metal contents in sediments would be available to copepods and would 

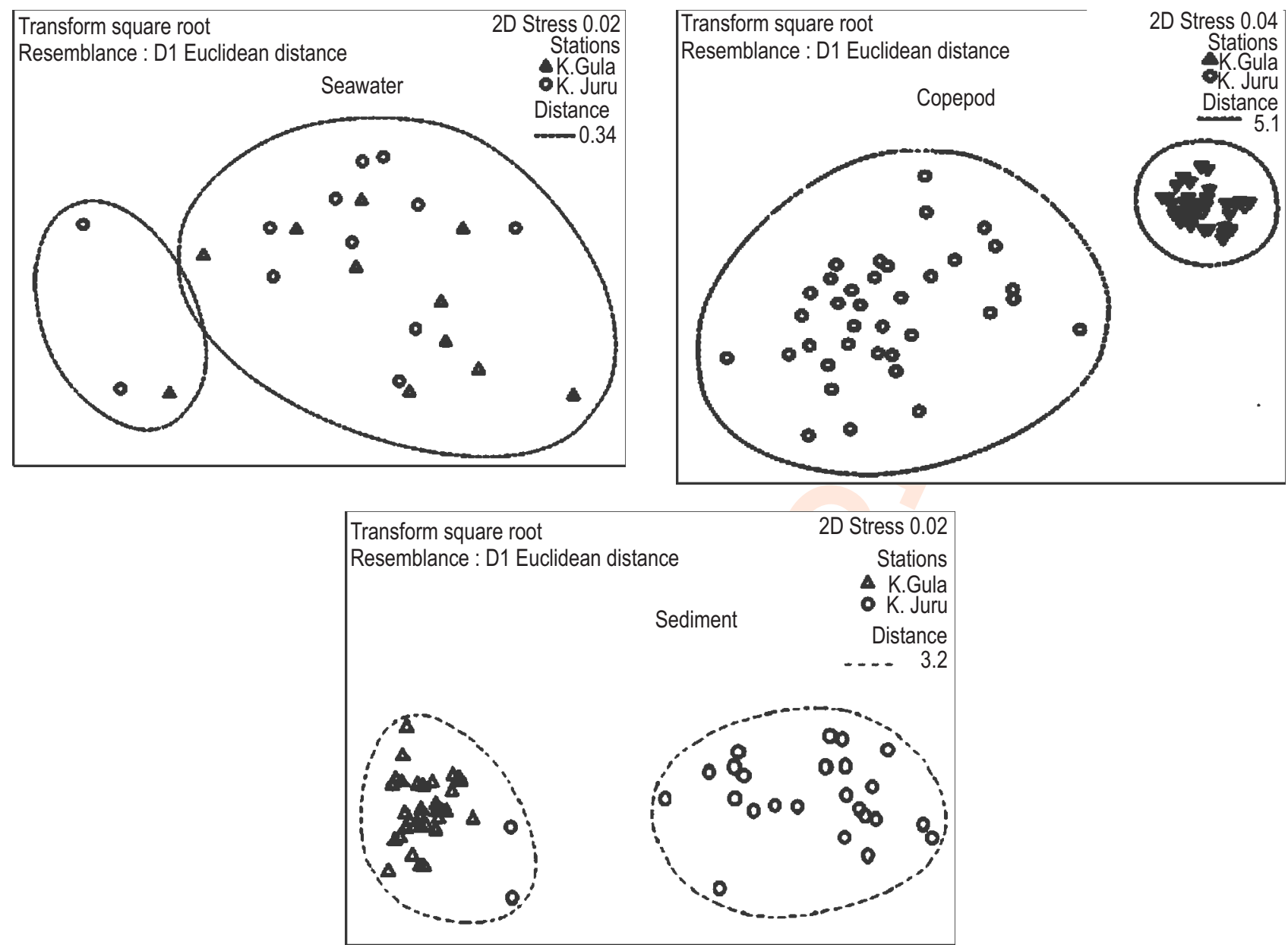

Fig. 8 Non-metric multidimensional scaling (NMDS) plot of heavy metal concentrations in copepods, seawater and sediment components of Juru and Gula estuaries throughout one-year study period.

affect the health of marine food chain. Fang et al. (2006) and Kadiene et al. (2019) reported that copepods have high capacity of accumulating and bioconcentrating trace metals and can be used as an effective biological indicator for assessing and monitoring metal contamination in marine environment. In addition, Wang and Fisher (1998) also noted higher fraction of metals found in copepods' soft tissues compared to those obtained from water indicating higher uptake rate of metals through ingestion of food particles compared to direct uptake from dissolved phase. Nriagu (1978), Rainbow and White (1989), Wang (2002) and Robin et al. (2012) noted that heavy metals were highly persistent in sediment and biological compartments, such as copepods, making them suitable markers for environmental health monitoring.

Partitioning of heavy metals ( $\mathrm{Cd}, \mathrm{Cu}, \mathrm{Pb}$ and $\mathrm{Zn}$ ) in various environmental and biotic compartments (seawater, copepods, and bottom sediments) was studied in unpolluted (Gula estuary) and polluted waters (Juru estuary). The polluted Juru estuary showed significantly higher heavy metal concentration in all compartments compared to those in unpolluted Gula estuary. This observation was supported by multidimensional scaling, which showed two distinct groups (locations) with different heavy metal contents. A positive correlation $(p<0.05)$ of heavy metal contents between copepods and sediments was found in the Juru estuary, but no significant correlation was noted in the unpolluted Gula area. Heavy metal concentrations in copepods showed in significant correlation with those in seawater in both estuaries, indicating that uptake of heavy metals by copepods was mainly through ingestion of heavy metal contaminated particulate matter rather than direct uptake from seawater. This study illustrates that copepods and sediments can serve as useful markers for environmental health monitoring due to persistent heavy metal contents in these compartments.

\section{Acknowledgments}

The Ministry of Higher Education Malaysia supported this study through JSPS ACORE Matching Fund, and the Ministry of 
Science, Technology and Innovation through the E-Science Project No.01-02-040392. JSPS Core to Core Program, B. AsiaAfrica Science Platforms is also duly acknowledged. Special thanks are extended to Mr. Nordin and Mr. Abu from the Malaysian Wildlife Department for their help during sampling and to their colleagues for their technical assistance.

\section{References}

Al-Imarah, F.J.M., T.A. Khalaf, S.G. Ajeel, A.Y. Khudhair and R. Saad: Accumulation of heavy metals in zooplanktons from Iraqi National Waters. Int. J. Mar. Sci., 8, 25-34 (2018).

Babji, A.S., M.S. Embong and W.W. Woon: Heavy metal contents in coastal water fishes of West Malaysia. Bull. Environ. Contam. Toxicol., 23, 830-836 (1979).

Balakrishnan, B., B.K. Sahu, J.K. Ranishree, A.V. Lourduraj, M. Nithyanandam, N. Packiriswamy and P. Panchatcharam: Assessment of heavy metal concentrations and associated resistant bacterial communities in bulk and rhizosphere soil of Avicennia marina of Pichavaram mangrove. India. Earth Sci., 76, 58 (2017).

Balogh, Z., S. Harangi, J.T. Kundra't, I. Gyulai, B. To'thme're'sz and E. Simon: Effects of anthropogenic activities on the elemental concentration in surface sediment of oxbows. Water Air Soil Pollut., 227, 13 (2016).

Barron, M.G.: Bioaccumulation and Bioconcentration in Aquatic Organisms. In: Handbook of Ecotoxicology (Eds.: D.J. Hoffman, B.A. Rattner, G.A. Burton, J. Cairns, Lewis and F.L.B. Raton). Lewis Publishers, CRC Press Company, Washington D.C., pp. 878-888 (1995).

Bhattacharya, B.D., D.C. Nayak, S.K. Sarkar, S.N. Biswas, D. Rakshit and M.K. Ahmed: Distribution of dissolved trace metals in coastal regions of Indian Sundarban mangrove wetland: A multivariate approach. J. Clean Prod., 96, 233-243 (2015).

Clarke, K.R. and R.M. Warwick: Change in marine communities: An approach to statistical analysis and interpretation. $2^{\text {nd }}$ Edn., Plymouth Routines in Multivariate Ecological Research (PRIMERE), Plymouth (2001).

Dauvalter, V.A.: Heavy metals in the bottom sediments of the Inari-Pasvik lake-river system. Water Resource, 25, 451-457 (1998).

Davies, A.G.: Pollutions studies with marine plankton. Part II. Heavy metals. Adv. Mar. Biol., 15, 381-508 (1978).

Dawson, E.J. and M.G. Macklin: Speciation of heavy metals in floodplain and flood sediments: A reconnaissance survey of the Aire Valley, West Yorkshire, Great Britain. Environ. Geochem. Hlth., 20, 67-76 (1998).

Duggan, S., A.D. McKinnon and J.H. Carleton: Zooplankton in an Australian tropical estuary. Estuar. Coasts, 31, 455-467 (2008).

Etim, L., E.R. Akpan and P. Muller: Temporal trends in heavy metal concentrations in the clam E. radiata (Bivalvia: Tellinacea Donacidae) from the Cross River, Nigeria. Rev. Tropical Hydrobiol., 24, 327-333 (1991).

Fang, T.H., J.S. Hwang, S.H. Hsiao and H.Y. Chen: Trace metals in seawater and copepods in the ocean outfall area off the northern Taiwan coast. Mar. Environ. Res., 61, 224-243 (2006).

Fatima, M., N. Usmani and M.M. Hossain: Heavy metal in aquatic ecosystem emphasizing its effect on tissue bioaccumulation and histopathology: AReview. J. Environ. Sci. Technol., 7, 1-15(2014). Gajbhiye, S.N., V.R. Nair, P.V. Narvekar and B.N. Desai: Concentration and toxicity in of some metals in zooplankton near shore waters of Bombay. Ind. J. Mar. Sci., 14, 181-183 (1985).

Haris, H., L.J. Looi, A.A. Zaharin, N.F. Mokhtar, N.A.A. Ayob, F.M. Yusoff, A.B. Salleh and S.M. Praveena: Geo-accumulation index and contamination factors of heavy metals $(\mathrm{Zn}$ and $\mathrm{Pb})$ in urban river sediment. Environ. Geochem. HIth., 39, 1259-1271 (2017).

Harte, J., C. Holdren, R. Schneider and C. Shirley: Toxics A to Z, A Guide to Everyday Pollution Hazards. University of California Press, Oxford, England (1991).

Hong, Y., W. Liao, Z. Yan, Y. Bai, C. Feng, Z. Xu and D. Xu: Progress in the research of the toxicity effect mechanisms of heavy metals on freshwater organisms and their water quality criteria in China, $\mathrm{J}$. Chem., 2020, Article ID 9010348 (2020).

IMPAK: Quarterly Bulletin of Department of Environment. Vol. 2. Ministry of Science, Technology and Environment Malaysia (1998).

ISO: ISO 11466 Soil Quality: Extraction of Trace Elements Soluble in Aqua Regia. International Organization for Standardization, Geneva, Switzerland (1995).

Jothy, A.A., E. Huschenbeth and U. Harms: On the detection of heavy metals, organochlorine, pesticides and poly-chlorinated biphenyls in fish and shellfish from the coastal waters of peninsula Malaysia. Arch. Fishereiwiss, 33, 161-206 (1983).

Kadiene, E., B. Ouddane, J.S. Hwang and S. Souissi: Bioaccumulation of metals in calanoid copepods by oral intake. Scientific Reports, Nature Publishing Group, 9,1-9 (2019)

Kalay, M. and M. Canli: Elimination of essential $(\mathrm{Cu}, \mathrm{Zn})$ and nonessential $(\mathrm{Cd}, \mathrm{Pb})$ metals from tissues of a freshwater fish Tilapia zillii following an uptake protocol. Turk. J. Zool., 24, 429-436 (2000).

Khan, M.I., K. Muhammad, A. Khan, N. Gulfam, M. Siraj, F.Z. Amadullah, S.H.F. Abidullah, S.N. Hamidullah, Z. Ali Shah and F. Qadir: Bioaccumulation of heavy metals in water, sediments, and tissues and their histopathological effects on Anodonta cygnea (Linea, 1876) in Kabul River, Khyber Pakhtunkhwa, Pakistan. BioMed. Res., 2018, Article ID 1910274 (2018)

Kontas, A.: Trace metals ( $\mathrm{Cu}, \mathrm{Mn}, \mathrm{Ni}, \mathrm{Zn}, \mathrm{Fe}$ ) contamination in marine sediment and zooplankton samples from Izmir Bay (Aegean Sea, Turkey). WaterAir Soil Poll., 188, 323-334 (2008).

Lacerda, L.D.: Biogeochemistry of trace metals and diffuse pollution in mangrove ecosystems. Inter. Soc. Mangrove Ecosys., 2, 1-72 (1998).

Law, A.T. and A. Singh: Heavy metals in fishes in the Klang Estuary, Malaysia. Malay. Nature J., 41, 505-513 (1988).

Leung, H.M., A.O. Leung, H.S. Wang, K.K. Ma, Y. Liang, K.C. Ho, K.C. Cheung, F. Tohidi and K.K. Yung: Assessment of heavy metals/metalloid ( $\mathrm{As}, \mathrm{Pb}, \mathrm{Cd}, \mathrm{Ni}, \mathrm{Zn}, \mathrm{Cr}, \mathrm{Cu}, \mathrm{Mn}$ ) concentrations in edible fish species tissue in the Pearl River Delta (PRD), China. Mar. Pollut. Bull., 78, 235-345 (2014).

Looi, L.J., A.Z. Aris, W.L. Wan-Johari, F.M. Yusoff and Z. Hashim: Baseline metals pollution profile of tropical estuaries and coastal waters of the Straits of Malacca. Mar. Pollut. Bull., 74, 471-476 (2013).

Looi, L.J., A.Z. Aris and F.M. Yusoff: Metals concentrations (Co, Ni, Pb, $\mathrm{Zn}$ ) in the estuarine and coastal waters from western part of Johor Strait. Malay. Nat. J., 66, 86-96 (2014).

Luorna, S.N.: Processes affecting metal concentrations in estuarine and 
coastal marine sediments. In: Heavy Metals in the Marine Environment (Eds.: R.W. Furness and P.S. Rainbow). CRC Press, Inc., Florida, pp. 1-66 (1990).

Lyons, W.B. and W.F. Fitzgerald: Trace metal fluxes to nearshore Long Island sound sediments. Mar. Pollut. Bull., 11, 157-161 (1980).

Machado, W., E.V. Silva-Filho, R.R. Oliveira and L.D. Lacerda: Trace metal retention in mangrove ecosystems in Guanabara Bay, SE Brazil. Mar. Pollut. Bull., 44, 1277-1280 (2002).

Mat, I. and M.J. Maah: Sediment trace metal concentrations from the Mudflats of Kuala Juru and Kuala Muda of Malaysia. Bull. Environ. Contam. Toxicol., 53, 740-746 (1994).

Nriagu, J.O.: Properties and the biogeochemical cycle of lead. In: The biogeochemistry of lead in the environment, Part A. (Ed.: J.O. Nriagu). Elsevier/North-Holland Biomedical Press, Amsterdam, pp. 1-14 (1978).

Rainbow, P. S. and S. L. White: Comparative strategies of heavy metal accumulation by crustaceans: zinc, copper and cadmium in a decapod, an amphipod and a barnacle. Hydrobiologia, 174, 245-262 (1989).

Rauf, A., M. Javed and G. Jabeen: Uptake and accumulation of heavy metals in water and planktonic biomass of the River Ravi, Pakistan. Turk. J. Fish. Aquat. Sci., 19, 857-864 (2018).

Rezai, H., F.M. Yusoff and K. Saed: Heavy metal concentrations in zooplankton and neuston from the Straits of Malacca. In: Proceedings of the $10^{\text {th }}$ JSPS Joint Seminar on Marine and Fishery Sciences (Eds.: M. Nasir Saadon, S.A.Abdullah, S.M.Sheriff and N.A. Ariffin). Sustainable Utilization of Marine Resources, pp. 219$228(1999)$.

Rezai, H., F.M. Yusoff and C.K. Yap: Mercury in zooplankton from the Malacca Straits. Indian J. Mar. Sci., 32, 222-225 (2003).

Robin, R.S., P.R. Mudulli, K. Vishmu Vardhan, D. Ganguly, K.R. Abhilassh and T. Balasubramanian: Heavy metal contamination and risk assessment in the marine environment of Arabian sea, along the southwest coast of India. Amr. J. Chem., 2, 191-208 (2012).

Sarkar, S.K.: Trace metals in a tropical mangrove wetland. Springer Nature Singapore Pte Ltd., pp. 261 (2017).

Salomons, W., N.M. de Rooij, H. Kerdijk and J. Bril: Sediments as a source for contaminants? Hydrobiologia, 149, 13-39 (1987).

Ščančar, J., R. Milačič and M. Horvat: Comparison of various digestion and extraction procedures in analysis of heavy metals in sediments. WaterAir Soil Pollut., 118, 87-99 (2000).

Schüürmann, G. and B. Markert: Ecotoxicology, Ecological Fundamentals, Chemical Exposure, and Biological Effects. John Wiley \& Sons Inc. and Spektrum Akademischer Verlag (1998).

Serranito, B., A. Aubert, L. Stemmann, N. Rossi and J.L. Jamet: Proposition of indicators of anthropogenic pressure in the Bay of Toulon (Mediterranean Sea) based on zooplankton time-series. Contin. She. Res., 121, 3-12 (2016).
Shartooh, S.M., M.N.A. Al-Azzawi and S.A.K. Al-Hiyali: Pomegranate peels as biosorbent material to remove heavy metal ions from industrial wastewater. Ira. J. Sci., 54, 823-831 (2013).

Tam, N.F.Y. and Y.S. Wong: Mangrove soils in removing pollutants from municipal wastewater of different salinities. J. Environ. Qual., 28, 556-564 (1999).

Turner, J.T.: The importance of small planktonic copepods and their roles in pelagic marine food webs. Zool. Stud., 43, 255-266 (2004).

Veena, B., C.K. Radhakrishnan and J. Chacko: Heavy metal induced biochemical effects in an estuarine teleost. Indian J. Mar. Sci., 26, 74-78(1997).

Wang, W.X.: Interactions of trace metals and different marine food chains. Mar. Ecol. Prog. Ser., 243, 295-309 (2002).

Wang, W.X. and N.S. Fisher: Accumulation of trace elements in a marine copepod. Limnol. Oceanogr., 43, 273-283 (1998).

Yap, C.K., A. Ismail, S.G. Tan and H. Omar: Concentrations of Cu and Pb in the offshore and intertidal sediments of the west coast of Peninsular Malaysia. Environ. Inter., 28, 467-497 (2002).

Yap, C.K., A. Ismail and S.G. Tan: Cd and Zn in the straits of Malacca and intertidal sediments of the west coast of Peninsular Malaysia. Mar. Pollut. Bull., 46,1348-1353 (2003).

Yap, C.K., A. Ismail and S.G. Tan: Heavy metal (Cd, Cu, Pb, and Zn) concentrations in the green-lipped mussel Perna viridis (L.) collected from some wild and aquacultural sites in the west coast of Peninsular Malaysia. Food Chem., 84, 569-570 (2004a).

Yap, C.K., A. Ismail, S.G. Tan and A.R. Ismail: The impact of anthropogenic activities on heavy metal ( $\mathrm{Cu}, \mathrm{Cd}, \mathrm{Pb}$, and $\mathrm{Zn}$ ) pollution: Comparison of metal levels in the green-lipped mussel Perna viridis (Linnaeus) and in the sediment from a high activity site at $\mathrm{Kg}$. Pasir Puteh and relatively low activity site at Pasir Panjang. Pert. J. Trop. Agricu. Sci., 27, 73-78 (2004b).

Yi, Y., Z. Wang, K. Zhang, G. Yu and X. Duan: Sediment pollution and its effect on fish through food chain in the Yangtze River. Int. J. Sediment Res., 23, 338-347 (2008).

Yunus, K., M.Y. Nurulnadia, M.S. Noor-Azhar, O.M. Chuan, S. Shahbudin, A.J.K. Chowdhury and J. Bidai: Heavy metal concentration in the surface sediment of Tanjung Lumpur mangrove Forest, Kuantan, Malaysia. Sains Malaysiana, 40, 89-92 (2011).

Zeitoun, M.M. and E.S.E. Mehana: Impact of water pollution with heavy metals on fish health: Overview and updates. Global Veterinaria, 12, 219-231 (2014).

Zetina-Rejón, M.J., F.A. Sánchez and E.A. Chávez: Trophic structure and flows of energy in the Huizache-Caimanero lagoon complex on the Pacific coast of Mexico. Estuar. Coa. Shelf Sci., 57, 803-815 (2003).

Zhou, Y.W., B. Zhao, Y. Peng and G. Chen: Influence of mangrove reforestation on heavy metal accumulation and speciation in intertidal sediments. Mar. Pollut. Bull., 60, 1319-13 (2010). 